\title{
Parathyroid Adenomas versus Four-gland Hyperplasia as the Cause of Primary Hyperparathyroidism in Patients with Prolonged Lithium Therapy
}

\author{
Samir S. Awad, M.D., ${ }^{1}$ Judiann Miskulin, M.D., ${ }^{2}$ Norman Thompson, M.D. ${ }^{2}$ \\ ${ }^{1}$ Michael E. DeBakey Department of Surgery, Baylor College of Medicine, Houston Veterans Administration Medical Center, Surgical Service (112), \\ 2002 Holcombe Boulevard, Houston, Texas 77030, USA \\ ${ }^{2}$ Department of Surgery, University of Michigan Hospitals, Taubman 2920, 1500 E. Medical Center Drive, Ann Arbor, Michigan 48109, USA
}

\begin{abstract}
Chronic lithium therapy in patients with affective psychiatric disorders has been implicated as the cause of hypercalcemia and primary hyperparathyroidism. Our objective was to evaluate whether primary hyperparathyroidism was caused by an adenoma or four-gland hyperplasia. The medical records of 15 patients with affective psychiatric disorders who were treated with chronic lithium therapy from 1982 to 1997 , all of whom were operated on for primary hyperparathyroidism, were reviewed. Data on age, symptoms, duration of lithium therapy, pre- and postoperative calcium levels, and parathyroid hormone levels were collected. Parathyroid histology for each patient was independently and blindly reviewed. The mean age was $58 \pm 10$ years, the mean duration of lithium therapy $10.7 \pm$ 6 years, and the mean preoperative calcium level $11.7 \pm 0.5 \mathrm{mg} / \mathrm{dl}$. All patients underwent bilateral neck exploration with selective resection of enlarged glands. Of the 15 patients, $14(92 \%)$ had adenomas (11 single, 3 double), and 1 (8\%) had four-gland hyperplasia. All patients were rendered eucalcemic, with a postoperative calcium level of $9.2 \pm 0.5 \mathrm{mg} / \mathrm{dl}(p<$ 0.005). All patients resumed their lithium therapy, with 1 of 15 patients developing recurrent hyperparathyroidism 2 years following the first operation; this patient required reexploration, at which time an adenoma was resected. In our experience hyperparathyroidism in patients who have undergone prolonged therapy with lithium is associated with a high incidence of parathyroid adenomas versus four-gland hyperplasia. This suggests that lithium selectively stimulates growth of parathyroid adenomas in susceptible patients, who are best treated with adenoma excision rather than subtotal parathyroidectomy.
\end{abstract}

Lithium therapy has proven to be highly effective for bipolar illness since its introduction in 1949. Garfinkel et al. were the first to suggest an association between prolonged lithium therapy and the development of hyperparathyroidism [1]. Since 1973 about 50 cases have been reported, suggesting enhanced occurrence of hyperparathyroidism in patients with affective psychiatric disorders treated by lithium [2]. Approximately $10 \%$ to $15 \%$ of lithium-treated patients become hypercalcemic, with laboratory evidence and symptoms of hyperparathyroidism. In these patients it remains unclear

This International Association of Endocrine Surgeons (IAES) article was presented at the 39th World Congress of Surgery International Surgical Week (ISW01), Brussels, Belgium, August 26-30, 2001.

Correspondence to: Samir S. Awad, M.D., e-mail: sawad@bcm.tmc.edu whether lithium initiates the disease or promotes underlying hyperparathyroidism. Previous studies have reported conflicting results that prolonged lithium therapy causes four-gland hyperplasia, and others report adenomas. We sought to review the cause of primary hyperparathyroidism in our population of patients with affective psychiatric disorders who had undergone treatment with prolonged lithium therapy.

\section{Patients and Methods}

The medical records of patients with a diagnosis of bipolar disorder who were treated with chronic lithium therapy and operated on for primary hyperparathyroidism from 1982 to 1997 were reviewed. During the study period 400 patients were identified with bipolar disorder, 348 of whom were on chronic lithium therapy. Of these patients, 15 were identified with hypercalcemia and underwent exploration (study group). The incidence of hyperparathyroidism in this cohort of patients is $4.3 \%$, which is higher than the $1 \%$ incidence reported for the normal population.

For each patient, age, symptoms (fatigue, bone pain, renal calculi, constipation), duration of lithium therapy, pre- and postoperative calcium levels, parathyroid hormone (PTH) levels, and location of their enlarged gland(s) were collected. Routine bilateral neck exploration was performed with the aim of identifying all four parathyroid glands. Enlarged glands were resected; and in the case of four-gland enlargement, a 3.5-gland resection was performed. Resected glands were sent to the pathology department to be weighed and permanent sections prepared for histologic diagnosis.

The parathyroid histology for each patient was independently reviewed and confirmed. The distinction between adenoma and hyperplasia was based on the combination of gross features and histologic parameters. A diagnosis of adenoma was made if microscopic examination revealed cohesive sheets of cells partly surrounded by a rim of normal glandular tissue with absent or scant adipose tissue [3]. In contrast, parathyroid hyperplasia was diagnosed if the resected gland was composed of mixed cellularity with stromal fat cells and scant normal glandular tissue present [3].

Data are presented as means \pm SEM. Univariate comparisons 
Table 1. Variables in patients treated with lithium for affective psychiatric disorders who developed primary hyperparathyroidism.

\begin{tabular}{|c|c|c|c|c|c|c|}
\hline Patient no. & Gender & Age (years) & $\begin{array}{l}\text { Duration of } \mathrm{Li}^{++} \\
\text {therapy (years) }\end{array}$ & $\begin{array}{l}\text { Daily dose of } \\
\mathrm{Li}^{++}(\mathrm{mg})\end{array}$ & Parathyroid pathology & $\begin{array}{l}\text { Location of } \\
\text { enlarged gland(s) }\end{array}$ \\
\hline 1 & $\mathrm{~F}$ & 66 & 11 & 900 & Single adenoma & RS \\
\hline 2 & $\mathrm{~F}$ & 57 & 21 & 600 & Single adenoma & LI \\
\hline 3 & $\mathrm{~F}$ & 74 & 24 & 300 & Single adenoma & LS \\
\hline 4 & $\mathrm{~F}$ & 59 & 7 & 300 & Single adenoma & RI, IT \\
\hline 5 & $\mathrm{~F}$ & 61 & 12 & 600 & Single adenoma & LI \\
\hline 6 & $\mathrm{~F}$ & 56 & 10 & 900 & Single adenoma & RS \\
\hline 7 & M & 60 & 3 & 600 & Single adenoma & RI \\
\hline 8 & M & 47 & 10 & 1600 & Single adenoma & LI \\
\hline 9 & $\mathrm{~F}$ & 58 & 7 & 450 & Double adenoma & $\mathrm{LS}, \mathrm{LI}$ \\
\hline 10 & $\mathrm{~F}$ & 66 & 2 & 1200 & Double adenoma & RI, LI \\
\hline 11 & $\mathrm{M}$ & 34 & 11 & 600 & Four-gland hyperplasia & All \\
\hline 12 & $\mathrm{~F}$ & 61 & 10 & 900 & Double adenoma & $\mathrm{RS}, \mathrm{LI}$ \\
\hline 13 & $\mathrm{~F}$ & 58 & 12 & 300 & Single adenoma & LI \\
\hline 14 & $\mathrm{~F}$ & 51 & 5 & 600 & Single adenoma & RI \\
\hline 15 & M & 63 & 9 & 900 & Single adenoma & RI \\
\hline
\end{tabular}

RS: right superior; RI: right inferior; LS: left superior; LI: left inferior; IT: intrathyroidal; $\mathrm{Li}^{++}$: lithium.

were made using the unpaired Student's $t$-test. A value of $p<0.05$ was significant. Correlation between groups was tested using the Spearman rank test.

\section{Results}

Altogether, 15 patients on chronic lithium therapy for affective psychiatric disorders developed symptomatic hyperparathyroidism during the study period and underwent bilateral neck exploration. The demographic data, duration of therapy with lithium, daily dose of lithium, and parathyroid histology are shown in Table 1 . The mean age was $58 \pm 10$ years; the mean duration of lithium therapy was $10.7 \pm 6$ years; and the mean preoperative calcium level was $11.7 \pm 0.5 \mathrm{mg} / \mathrm{dl}$. The patient's symptoms are shown in Table 2 . Symptoms included fatigue, constipation, bone pain, bone fractures, and renal stones. All patients underwent bilateral neck exploration with selective resection of enlarged glands.

Histological review revealed adenomas in $92 \%$ of patients $(14 /$ 15 ; single 11 , double 3 ). Of the 15 patients, 1 (8\%) had four-gland hyperplasia and underwent 3.5-gland resection. All patients were rendered eucalcemic with a postoperative calcium level of $9.2 \pm 0.5$ $\mathrm{mg} / \mathrm{dl}$ ( $p<0.005$, compared to preoperative levels). All patients resumed their lithium therapy with improvement in their nonpsychiatric symptoms of hyperparathyroidism. Of the 15 patients, 1 developed recurrent hyperparathyroidism 2 years following the initial operation, having resumed lithium therapy for his bipolar disease (follow-up 2-17 years). The patient required neck reexploration, and an adenoma was resected; the other two glands appeared normal. There was poor correlation between the duration of lithium therapy and the histology (adenoma or hyperplasia) $(R=0.16)$. Also there was poor correlation between the duration of lithium therapy and preoperative calcium levels $(R=0.33)$.

\section{Discussion}

Lithium-induced hyperparathyroidism is relatively uncommon and has been reported in only 49 patients to date [4-11]. Altogether, 33 patients had parathyroid adenomas, and 16 had parathyroid hyperplasia. Calcium levels of patients on chronic lithium therapy have been shown to be elevated in $15 \%$ to $20 \%$ and may be a direct effect of lithium on PTH secretion [12, 13]. In most patients lithium-
Table 2. Symptoms of hyperparathyroidism in patients on chronic lithium therapy.

\begin{tabular}{llr}
\hline Symptom & No. & $\%$ \\
\hline Constipation & 3 & 20.0 \\
Fatigue & 7 & 46.7 \\
Nephrolithiasis & 2 & 13.3 \\
Abdominal pain & 1 & 6.7 \\
Bone pain & 2 & 13.3 \\
\hline
\end{tabular}

induced hyperparathyroidism is reversible when lithium is withdrawn, but for many patients continued therapy is a necessity.

To date, the evidence is inconclusive as to whether chronic stimulation with lithium has a provoking versus a causal role in the development of hyperparathyroidism. In vitro, in bovine parathyroid cells it has been shown that lithium blunts the normal cytosolic calcium response and augments the normal PTH secretory response to changes in extracellular calcium $[14,15]$. In vivo studies show that lithium directly stimulates PTH secretion [16, 17]. It also affects calcium metabolism at the renal level and accelerates loss of bone density $[10,11]$.

It seems intuitive that the above-mentioned alterations should cause hyperplastic changes, rather than adenoma formation, as all four parathyroid glands are exposed to high serum levels of lithium. It has been proposed that lithium stimulates the entire parathyroid mass, resulting in hyperplasia [18]. A threefold increase in parathyroid volume has been documented by ultrasonography in patients treated with lithium for a median of 8 years [19]. The literature does not support this supposition, with 16 of 49 reported cases showing parathyroid hyperplasia as the cause of hyperparathyroidism. Moreover, the mean duration of therapy in our study group was more than 10 years, with only one patient having parathyroid hyperplasia.

Alternatively, it has been suggested that chronic therapy with lithium may unmask preexisting primary hyperparathyroidism by serving as a mitogen promoting adenoma formation or by accelerating growth in preexisting abnormal parathyroid tissue [16, 19]. Data from recent studies show an increase in DNA synthesis in cells from parathyroid adenomas that was greater than that for cells from hyperplastic parathyroid glands; there was no growth in normal cells [19-21]. This possibility is supported by the fact that parathyroid adenomas have been reported more often than hyperplasia 
in patients on long-term lithium therapy (33 of 49 reported cases). Our findings that most patients $(92 \%)$ had parathyroid adenomas corroborate this hypothesis. Additionally, in our report, the duration of therapy did not correlate with the presence of hyperplasia or an adenoma.

Many patients on chronic lithium therapy have symptoms of hyperparathyroidism, such as decreased energy, easy fatigability, constipation, and renal stones, all of which were found in our patients. For patients who require ongoing treatment with lithium, surgery is indicated. Based on our findings, we advocate continued routine bilateral neck exploration with inspection of all four glands. These patients may not be optimal candidates for minimally invasive parathyroid resection because of the observed incidence of double adenomas. Excision should be limited to evident disease.

\section{Conclusions}

Review of the pathology of patients on chronic lithium therapy who developed symptomatic hyperparathyroidism revealed adenomas to be the predominant cause of the hyperparathyroidism. This is consistent with most of the cases previously reported.

Résumé. La prise de lithium à long cours chez le patient atteint de désordre psychiatrique affectif peut être responsable d'hypercalcémie et d'hyperparathyrö̈die primitive (HPTp). Notre objectif a été d'évaluer si l'HPTp était en rapport avec un adénome ou une hyperplasie des quatre glandes. On a revu les dossiers médicaux de 15 patients atteints de troubles psychiatriques traités au long cours par le lithium, tous opérés pour HPTp entre 1982-1997. On a colligé les données en ce qui concerne l'âge, les symptômes, la durée du traitement par le lithium, les taux de calcémie préet postopératoires, ainsi que les taux de PTH. On a obtenu une histologie de la parathyroïde pour chaque patient, qui a été revue de façon indépendante et aveugle. L'âge moyen a été de $58 \pm 10$ ans. La durée moyenne de thérapeutique par le lithium a été de $10.7 \pm 6$ ans. La calcémie préopératoire moyenne a été de $11.7 \pm 0.5 \mathrm{mg} / \mathrm{dl}$. Tous les patients ont eu une exploration bilatérale du cou avec une résection sélective de toute glande augmentée de volume. Quatorze des quinze patients (92\%) avaient des adénomes (11 uniques, 3 doubles). Un des quinze patients (8\%) avait une hyperplasie des quatre glandes. Tous les patients étaient eucalcémiques avec une calcémie postopératoire de $9.2 \pm 0.5(p<0.005)$. Tous les patients ont pu reprendre leur lithium et seulement un des 15 patients a développé une HPTp récidivante 6 ans après sa première intervention et a nécessité une réexploration avec résection pour adénome. Dans notre expérience, l'hyperparathyroïdie chez les patients ayant eu un traitement prolongé par le lithium est associée à une incidence élevée d'adénome par rapport à l'hyperplasie des quatre glandes. Ces résultats suggèrent que le lithium stimule de façon sélective la croissance des adénomes de la parathyroïde: ces patients sont mieux traités par excision de leur adénome plutôt que par une parathyrö̈dectomie subtotale.

Resumen. La terapia crónica con el litio en pacientes con alteraciones psiquiátricas afectivas ha sido inculpada como causa de hipercalcemia e hiperparatiroidismo primario. Nuestro propósito fue evaluar si tal hiperparatiroidismo primario fue causado por un adenoma o por hiperplasia de cuatro glándulas. Se revisaron las historias de 15 pacientes atendidos entre 1982 y 1997 que sufrían alteraciones psiquiátricas afectivas y que recibieron terapia crónica con litio y que fueron sometidos a operación por hiperparatiroidismo primario. Se efectuó el registro de la edad, los síntomas, la duración de la terapia con litio, los niveles pre y postoperatorios de calcio y los niveles de parathormona, y se hizo la revisión ciega e independiente de la histología paratiroidea. La edad promedio fue $58 \pm 10$ años. El promedio de la duración de la terapia con litio fue $10.7 \pm 6$ años. El nivel promedio del calcio sérico fue $11.7 \pm 0.5$ $\mathrm{mg} / \mathrm{dl}$. Se realizó exploración cervical bilateral en la totalidad de los pacientes, con resección selectiva de las glándulas de tamaño aumentado. Catorce de 15 pacientes ( $(92 \%)$ presentaron adenomas (11 únicos, 3 dobles), y sólo $1(8 \%)$ presentó hiperplasia de cuatro glándulas. Todos los pacientes convirtieron a eucalcemia, con un sodio sérico postoperatorio promedio de $9.2 \pm 0.5(p<0.005)$. Todos reasumieron la terapia con litio y uno de los 15 desarrolló hiperparatiroidismo recurrente 6 años luego de la operación, lo cual requirió reexploración y resección de un adenoma. En nuestra experiencia, el hiperparatiroidismo en pacientes que reciben terapia prolongada con litio se asocia con una elevada incidencia de adenomas paratiroideos versus hiperplasia de cuatro glándulas, lo cual sugiere que el litio puede estimular el crecimiento de adenomas paratiroideos en pacientes susceptibles, quienes entonces deben ser tratados con resección del adenoma en vez de paratiroidectomía subtotal.

\section{References}

1. Garfinkel PE, Ezrin C, Stancer HC. Hypothyroidism and hyperparathyroidism associated with lithium. Lancet 1973;2:331-332

2. Abdullah H, Bliss R, Guinea AI, et al. Pathology and outcome of surgical treatment for lithium-associated hyperparathyroidism. Br. J. Surg. 1999;86:91-93

3. Clark OH, Quan-Yang D. Textbook of Endocrine Surgery, Philadelphia, Saunders, 1997;281-287

4. Mallette LE. Acute and chronic effects of lithium on human calcium metabolism. Lithium 1991;2:209-226

5. Nordenstrom J, Strigard K, Perbeck L, et al. Hyperparathyroidism associated with treatment of manic-depressive disorders by lithium. Eur. J. Surg. 1992;158:207-211

6. Rabin PL, Evans DC. Exopthalmos and elevated thyroxine levels in association with lithium therapy. J. Clin. Psychiatry 1981;42:398-400

7. Krivitzky A, Bentata-Pessayre M, Sarfati E, et al. Lesions hypersecretantes multiples des parathyroides au cours d'un traitement par le lithium. Ann. Med. Interne (Paris) 1986;137:118-122

8. Feldman MG, Pachman JS. Surgical management of lithium-induced hypercalcemia. Conn. Med. 1990;54:614-615

9. Ananth J, Wohl M, Zegers C, et al. Hyperparathyroid adenoma with lithium therapy. Lithium 1991;2:54-57

10. Labussiere A-S, Delarnare N, Brochier T, et al. Lithium, hyperparathyroidism and parathyroid adenoma [letter]. Ann. Med. Interne (Paris) 1993;144:136-137

11. Bendz H, Sjodin I, Toss G, et al. Hyperparathyroidism and long-term lithium therapy: a cross-sectional study and the effect of lithium withdrawal. J. Intern. Med. 1996;240:357-365

12. Davis BM, Pfefferbaum A, Krutzik S, et al. Lithium's effect of parathyroid hormone. Am. J. Psychiatry 1981;138:489-492

13. Christiansen C, Baastrup PC, Transbol I. Development of "primary" hyperparathyroidism during lithium therapy: longitudinal study. Neuropsychobiology 1980;6:280-283

14. McHenry CR, Racke F, Meister M, et al. Lithium effects on dispersed bovine parathyroid cell grown in tissue culture. Surgery 1991;110:10611066

15. Wallace J, Scarpa A. Similarities of $\mathrm{Li}^{+}$and low $\mathrm{Ca}^{2+}$ in the modulation of secretion by parathyroid cells in vitro. J. Biol. Chem. 1983;258:62886292

16. Christensson TAT. Lithium, hypercalcaemia, and hyperparathyroidism. Lancet 1976;2:144

17. Shen F, Sherrard DJ. Lithium-induced hyperparathyroidism: an alteration of the "set point. Ann. Intern. Med. 1982;96:63-65

18. McHenry CR, Rosen IB, Rotstein LE, et al. Lithimugenic disorders of the thyroid and parathyroid glands as surgical disease. Surgery 1990; 108:1001-1005

19. Mallette LE, Khouri K, Zengoitita $\mathrm{H}$, et al. Lithium treatment increases intact and midregion parathyroid hormone and parathyroid volume. J. Clin. Endocrinol. Metab. 1989;68:654-660

20. Saxe AW, Gibson G. Lithium increases tritiated thymidine uptake by abnormal human parathyroid tissue. Surgery 1991;110:1067-1077

21. Saxe A, Gibson G, Silveira E. Effects of long-term lithium infusion on normal parathyroid tissue. Surgery 1995;117:577-580 